\title{
TECHNOLOGY FOR SUGARCANE AGROINDUSTRY WASTE REUSE AS GRANULATED ORGANOMINERAL FERTILIZER
}

Doi:http://dx.doi.org/10.1590/1809-4430-Eng.Agric.v35n 1p 63-75/2015

\section{MARCÍLIO N. DO A. GURGEL ${ }^{2}$, SIMONE T. R. CORREA ${ }^{3}$, DURVAL DOURADO NETO $^{4}$, DURVAL R. DE PAULA JÚNIOR ${ }^{5}$}

\begin{abstract}
Aiming to evaluate the use of sugarcane industry waste such as byproducts from vinasse concentration process, it was assessed the organomineral fertilizer BIOFOM (concentrated vinasse, filter cake, boiler ash, soot from chimneys and supplemented with mineral fertilizers). The study included characterization and agronomic potential analysis of a test plant (corn), by noting the differences between mineral fertilizers and BIOFOM fertilization until 45 days after sowing. The technology traditionally used to produce BIOFOM was based on vinasse evaporation with high heat transfer coefficients. It was observed that the technology, which can be formulated according to the needs of any crop, could be used in many cases as mineral fertilizer. Therefore, the use of this organomineral fertilizer reduces waste generation of sugarcane ind ustry.
\end{abstract}

KEYWORDS: biofertilizer, vinasse, sugarcane agribusiness, organic waste, filter cake.

\section{TECNOLOGIA PARA APROVEITAMENTO DE RESÍDUOS DA AGROINDÚSTRIA SUCROALCOOLEIRA COMO BIOFERTILIZANTE ORGANOMINERAL GRANULADO ${ }^{1}$}

\begin{abstract}
RESUMO: Com o objetivo de avaliar o uso de resíduos da agroindústria sucroalcooleira como vantagens do processo de concentração da vinhaça, utilizou-se o BIOFOM (biofertilizante organomineral formulado com vinhaça concentrada, torta de filtro, cinzas de caldeira e fuligem das chaminés, e complementado com fertilizantes minerais). O presente estudo contemplou a caracterização e a análise do potencial agronômico envolvendo uma planta-teste (milho), observando as diferenças entre os tratamentos (adubação com fertilizante mineral versus adubação com BIOFOM), até 45 dias após a semeadura. A tecnologia (tradicionalmente usada para a produção do BIOFOM) utilizada para concentrar a vinhaça baseou-se na evaporação do resíduo com elevados coeficientes de troca térmica. Observou-se que o BIOFOM, que pode ser formulado de acordo com as necessidades de qualquer cultura, pode substituir, parcial ou totalmente, a utilização do fertilizante mineral. O produto reduz a geração de resíduos da agroindústria sucroalcooleira.
\end{abstract}

PALAVRAS-CHAVE: biofertilizante, vinhaça, agroindústria canavieira, resíduos orgânicos, torta de filtro.

\footnotetext{
${ }^{1}$ The present paper is part of the first author's dissertation presented to the FEAGRI-UNICAMP, being a major accomplishment to obtain $\mathrm{PhD}$ degree in Agricultural Engineering.

${ }^{2}$ Eng $^{\circ}$ A grônomo, Doutor, Engenharia de Desenvolvimento, Dedini S/A Indústrias de Base/Piracicaba-SP, Fone: (19) 98154 8730, marcilio.gurgel@terra.com.br.

${ }^{3}$ Eng ${ }^{a}$ Agrônoma, Pós-Doutoranda, Programa de Sustentabilidade, Laboratório Nacional de Ciên cia e Tecnologia do Bioetanol (CTBE)/Campinas-SP, simone.correa@bioetanol.org.br.

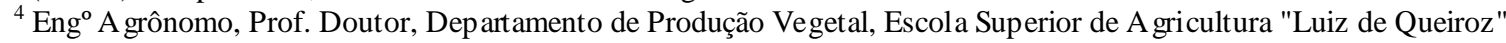
(ESALQ)/Piracicaba-SP, d.dourado@ gmail.com.

${ }^{5}$ Eng $^{\circ}$ Civíl, Prof. Livre Docente, Departamento de Água e Solo, Faculdade de Engenharia Agrícola, Universidade Estadual de Campinas, Campinas - SP.
}

Recebido pelo Conselho Editorial em: 02-10-2012

Aprovado pelo Conselho Editorial em: 02-9-2014 


\section{INTRODUCTION}

The National Alcohol Program (PROALCOOL), created in 1975 to stimulate the production of ethanol in order to meet the needs of the domestic and foreign markets and the automotive fuels policy (SILVA \& FISCHETTI, 2008), first drove the remarkable expansion of sugarcane farming. From this date, a major expansion of sugarcane activity was promoted in Brazil, as well as its concentration in certain areas and agricultural regions, especially in areas of the state of São Paulo. The second major thrust in sugar cane industry was the introduction of vehicles powered by gasoline and ethanol (flex-fuel) in 2003, and the worldwide movement pro-use of renewable fuels, from the mid-2000s on (RAMOS et al., 2008).

The environmental issue, however, has not received the same concern as the increase in production. Essential factors for sustainable development of sugarca ne production were never taken into account. With population growth, in the vast majority urban, and increased industrial development, water and solid wastes have been generated in large quantities (TASSO JÚNIOR et al., 2007). This fact resulted in intensification of major environmental problems such as degradation of ecosystems, atmospheric pollution caused by fires and pollution of watercourses and ground water caused by excessive application of vinasse "in natura" (SZMRECSÁNYI, 1994).

Some successful experiences with waste management in power plants and distilleries show that the filter cake, solid organic material obtained from sugar production, has been used in the fertilization of sugarcane crops. The sugarcane bagasse, which was already being used to generate energy in industrial units, has also been used in recent years in energy cogeneration, allowing power plants and distilleries not to consume electricity from distribution networks.

Vinasse is a byproduct from alcohol manufacture, being composed mostly of water (CÓ JUNIOR et al., 2008) and is the main effluent of the distilleries by fermentation, which had previously released directly into rivers, causing severe environmental problems. Nowadays, it is largely used to irrigate and fertilize sugarcane fields. It must be mentioned that the use of wastes deserves attention for possible problems concerning soil and water degradation and contamination (SPADOTTO, 2008).

Since waste production from sugarcane processing is quite voluminous, for both ethanol and sugar, the search for appropriate technologies to promote the management, treatment and use, constitutes a determining factor for an environmentally sustainable development of the sugarcane agro-ind us trial complex.

In this context, this research aimed to evaluate a patented organic fertilizer and commercially known as BIOFOM produced with waste from sugar and alcohol industry (concentrated vinasse, filter cake, boiler ash and soot from chimneys), and supplemented with mineral fertilizers to obtain equivalent formulations to those used in conventional fertilization of sugar cane.

\section{MATERIAL AND METHODS}

The experiment with BIOFOM, using corn as "test plant", was carried out from October to December 2008 in a greenhouse at the Department of Soil Sciences from the "Luiz de Queiroz" College of Agriculture, University of São Paulo, in Piracicaba (SP), Brazil. The location is at 547 meters of altitude and $22^{\circ} 43^{\prime} 31^{\prime \prime} \mathrm{S}$ latitude and $47^{\circ} 38^{\prime} 57^{\prime \prime} \mathrm{W}$ longitude. The greenhouse has 200 $\mathrm{m}^{2}$, with East-West orientation and plastic cover, and a moistened air circulation through a Pad House system performed the environmental cooling.

The agronomic potential of BIOFOM was evaluated through fertilizer lots that were produced with vinasse, filter cake, ash and soot; and supplemented with chemical fertilizers and granulated.

As shown in the Table 1, the experimental design was in randomized blocks consisting of 25 treatments and four replications: (i) Control; (ii) Molasses vinasse BIOFOM + broth with $30 \%$ and $45 \%$ of total soluble solids (TSS) $+50 \%, 75 \%$ and $100 \%$ mineral fertilizer; (iii) Molasses vinasse BIOFOM with $30 \%$ and $45 \%$ of TSS $+50 \%, 75 \%$ and $100 \%$ of the mineral fertilizer dose; (iv) 
Broth vinasse BIOFOM with $30 \%$ and $45 \%$ TSS $+50 \%$, $75 \%$ and $100 \%$ of the mineral fertilizer dose; (v) Mineral fertilizer equivalent to $100 \%, 75 \%$ and $50 \%$ of the dose; (vi) Molasses vinasse + concentrated broth at $30 \%$ of TSS + complement; (vii) Concentrated molasses vinasse at $30 \%$ of TSS + complement and; (viii) Concentrated broth vinasse at $30 \%$ of TSS + complement. The comparisons of the differences between treatments were performed by Tukey test (significance level of 5\%). For statistical analys is it was used the software SAS 9.2 (Statistical Analysis System).

TABLE 1. Treatments ( $\mathrm{T}$ ) of the experiment to evaluate the Biofom with corn (test plant).

\begin{tabular}{|c|c|}
\hline Composition & Abreviation \\
\hline 1 Control: soil corrected with limestone & Control \\
\hline $\begin{array}{l}\text { Molasses vinasse BIOFOM + broth with } 30 \% \text { of total soluble solids (TSS) }+50 \% \text { mineral } \\
\text { fertilizer }(0.823 \mathrm{~g} \text { of urea, } 1.626 \mathrm{~g} \text { of triple superphosphate and } 1.289 \mathrm{~g} \mathrm{of} \mathrm{KCl})\end{array}$ & Mixed 30-50 \\
\hline $\begin{array}{l}\text { Molasses vinasse BIOFOM + broth with } 30 \% \text { TSS }+75 \% \text { mineral fertilizer dose }(1.234 \mathrm{~g} \\
\text { urea, } 2.439 \mathrm{~g} \text { of triple superphosphate and } 1.933 \mathrm{~g} \text { of } \mathrm{KCl})\end{array}$ & Mixed 30-75 \\
\hline $\begin{array}{l}4 \text { Molasses vinasse BIOFOM + broth with } 30 \% \text { TSS }+100 \% \text { mineral fertilizer dose }(1.645 \mathrm{~g} \\
\text { urea, 3.252 g of triple superphosphate and } 2.577 \mathrm{~g} \text { of } \mathrm{KCl})\end{array}$ & Mixed 30-100 \\
\hline 5 Molasses vinasse BIOFOM + broth with $45 \%$ of ST $+50 \%$ mineral fertilizer dose & Mixed 45-50 \\
\hline 6 Molasses vinasse BIOFOM + broth with $45 \%$ of TSS $+75 \%$ mineral fertilizer dose & Mixed 45-75 \\
\hline 7 Molasses vinasse BIOFOM + broth with $45 \%$ of TSS $+100 \%$ of the mineral fertilizer dose & Mixed 45-100 \\
\hline 8 Molasses vinasse BIOFOM with $30 \%$ of TSS $+50 \%$ of the mineral fertilizer dose & $\begin{array}{l}\text { Molasses 30- } \\
50\end{array}$ \\
\hline 9 Molasses vinasse BIOFOM with $30 \%$ of TSS $+75 \%$ of the mineral fertilizer dose & $\begin{array}{l}\text { Molasses 30- } \\
75\end{array}$ \\
\hline 10 Molasses vinasse BIOFOM with $30 \%$ TSS $+100 \%$ of the mineral fertilizer dose & $\begin{array}{l}\text { Molasses 30- } \\
100\end{array}$ \\
\hline 11 Molasses vinasse BIOFOM with $45 \%$ of TSS $+50 \%$ of the mineral fertilizer dose & $\begin{array}{l}\text { Molasses 45- } \\
50\end{array}$ \\
\hline 12 Molasses vinasse BIOFOM with $45 \%$ of TSS $+75 \%$ of the mineral fertilizer dose & $\begin{array}{l}\text { Molasses 45- } \\
75\end{array}$ \\
\hline 13 Molasses vinasse BIOFOM with $45 \%$ of TSS $+100 \%$ of the mineral fertilizer dose & $\begin{array}{l}\text { Molasses 45- } \\
100\end{array}$ \\
\hline 14 Broth vinasse BIOFOM with $30 \%$ TSS $+50 \%$ of the mineral fertilizer dose & Pure $30-50$ \\
\hline 15 Broth vinasse BIOFOM with $30 \%$ TSS $+75 \%$ of the $m$ & Pure $30-75$ \\
\hline 16 Broth vinasse BIOFOM with $30 \%$ TSS $+100 \%$ of the $r$ & Pure $30-100$ \\
\hline 17 Broth vinasse BIOFOM with $45 \%$ of TSS $+50 \%$ of & Pure $45-50$ \\
\hline 18 Broth vinasse BIOFOM with $45 \%$ of TSS + & Pure 45-75 \\
\hline 19 Broth vinasse BIOFOM with $45 \%$ of TSS $+100 \%$ of the & Pure $45-100$ \\
\hline $\begin{array}{l}\text { Mineral fertilizer equivalent to } 100 \% \text { of the dose }(500 \mathrm{~kg} \text { of } 4-20-20(\mathrm{~N}, \mathrm{P}, \mathrm{K})+30 \mathrm{~kg} \text { of } \\
\mathrm{N} \text { in coverage) } *\end{array}$ & Mineral 100 \\
\hline 21 Mineral fertilizer equivalent to $75 \%$ of the dose & \\
\hline tilizer equivalent to $50 \%$ of the & Mineral 50 \\
\hline $30 \%$ of TSS + complement & Mixed \\
\hline 24 Con & Molasses \\
\hline 25 Concentrated broth vinasse at $30 \%$ of $\mathrm{T}$ & Pure \\
\hline
\end{tabular}

* Reference values - 100\%: 50, 100 and 100kg.ha-1 of N, P2O5 and K2O, respectively, this formulation adopted for being the most representative and standard in planting sugar cane in Mills in the Center-South of Brazil. In treatments $\mathrm{T}_{23}, \mathrm{~T}_{24}$ and $\mathrm{T}_{25}$, complementation was made in order to match the quantities of nitrogen, phosphorus and potassium applied in Treatment $20\left(\mathrm{~T}_{20}\right)$.

The concentrated vinasse is derived from water evaporation process by the TASTE technology (Thermally Accelerated Short Time Evaporation system) (GURGEL, 2012). Vinasse of treatments came from three origins: (i) Mixed - vinasse from sugar and ethanol plant; (ii) Molasses vinasse from a sugar mill; (iii) Broth - vinasse from an ethanol plant. Treatments took as a basis for comparison the amounts of $\mathrm{N}, \mathrm{P}$ and $\mathrm{K}$ from the mineral fertilizer 100, 75 and 50\%. Treatments of concentrated vinasse with $30 \%$ total soluble solids (TSS $30=22{ }^{\circ}$ Brix, vinasse concentrated \pm 10 times) and $45 \%$ of total soluble solids (TSS $45=55{ }^{\circ}$ Brix vinasse concentrated \pm 15 times) had the 
same source of (i) (ii) and (iii), and were also supplemented with chemical nutrients, as well as the BIOFOM treatments with $30 \%$ and $45 \%$ of total soluble solids.

BIOFOM preparation followed the method proposed by GURGEL (2009a, b), according to the following proportions: 10.7 (filter cake): 9.8 (vinasse with 30 or $45 \%$ of TSS): 5.0 (additives): 3.0 (molasses): 2.4 (ash): 1.5 (soot): 1.7 (urea): 1.0 (KCl) (by weight). Fertilizer granulation was made in dispersing discs driven by a $3 \mathrm{hp}$ engine and 1710-rpm rotation, in which a reducer was installed to decrease disc rotation to $35 \mathrm{rpm}$. First, the quantified mixture of dry filter cake + boiler ashes + chimney soot was placed on the disc, and then concentrated vinasse containing 30 or $45 \%$ soluble solids was sprinkled, depending on the treatment. Together with the byproducts, three additives were added (polymer resin and humectant), which were responsible for stability of the final granules. Granule hardness of around $2.0 \mathrm{kgf.cm}{ }^{-2}$ was expected for this method and final bead humidity near $8 \%$, considering that the moisture removed in the dryer for storage ranged between 30 and $40 \%$.

Once prepared with pure broth, molasses and mixed broth, the BIOFOM was characterized by physical-chemical analysis, performed at the Mineral Plant Nutrition Laboratory of the "Luiz de Queiroz" College of Agriculture, University of São Paulo.

The amounts of urea, total soluble solids and potassium chloride in the different treatments of BIOFOM and vinasse are described in Table 2.

TABLE 2. Amounts of urea, total soluble solids (ST) and potassium chloride (KCl) in the different treatments of BIOFOM and vinasse, in $\mathrm{g} \mathrm{plot}^{-1}$.

\begin{tabular}{|c|c|c|c|c|c|c|c|}
\hline \multirow{2}{*}{ Treatments } & \multirow[b]{2}{*}{ Source } & \multicolumn{3}{|c|}{ BIOFOM } & \multicolumn{3}{|c|}{ Vinasse } \\
\hline & & Urea & TSS & $\mathrm{KCl}$ & Urea & TSS & $\mathrm{KCl}$ \\
\hline 1 Control & Limestone & - & - & - & - & - & - \\
\hline 2 Mixed 30-50 & Limestone+BIOFOM & 0.981 & 0.538 & 0.780 & - & - & - \\
\hline 3 Mixed 30-75 & Limestone+BIOFOM & 1.472 & 0.807 & 1.170 & - & - & - \\
\hline 4 Mixed 30-100 & Limestone+BIOFOM & 1.963 & 1.077 & 1.560 & - & - & - \\
\hline 5 Mixed 45-50 & Limestone+BIOFOM & 0.894 & 0.544 & 0.780 & - & - & - \\
\hline 6 Mixed 45-75 & Limestone+BIOFOM & 1.340 & 0.816 & 1.170 & - & - & - \\
\hline 7 Mixed 45-100 & Limestone+BIOFOM & 1.787 & 1.088 & 1.560 & - & - & - \\
\hline 8 Molasses 30-50 & Limestone+BIOFOM & 0.432 & 0.439 & 0.780 & - & - & - \\
\hline 9 Molasses 30-75 & Limestone+BIOFOM & 0.648 & 0.658 & 1.170 & - & - & - \\
\hline 10 Molasses $30-100$ & Limestone+BIOFOM & 0.864 & 0.878 & 1.560 & - & - & - \\
\hline 11 Molasses 45-50 & Limestone+BIOFOM & 0.709 & 0.481 & 0.780 & - & - & - \\
\hline 12 Molasses 45-75 & Limestone+BIOFOM & 1.064 & 0.722 & 1.170 & - & - & - \\
\hline 13 Molasses 45-100 & Limestone+BIOFOM & 1.418 & 0.963 & 1.560 & - & - & - \\
\hline 14 Pure $30-50$ & Limestone+BIOFOM & 0.657 & 0.496 & 0.780 & - & - & - \\
\hline 15 Pure $30-75$ & Limestone+BIOFOM & 0.985 & 0.744 & 1.170 & - & - & - \\
\hline 16 Pure $30-100$ & Limestone+BIOFOM & 1.314 & 0.993 & 1.560 & - & - & - \\
\hline 17 Pure 45-50 & Limestone+BIOFOM & 0.958 & 0.630 & 0.780 & - & - & - \\
\hline 18 Pure $45-75$ & Limestone+BIOFOM & 1.436 & 0.945 & 1.170 & - & - & - \\
\hline 19 Pure $45-100$ & Limestone+BIOFOM & 1.915 & 1.260 & 1.560 & - & - & - \\
\hline 20 Mineral 100 & Limestone+4-20-20 & - & - & - & 0.411 & 0.813 & 0.644 \\
\hline 21 Mineral 75 & Limestone+4-20-20 & - & - & - & 0.308 & 0.610 & 0.483 \\
\hline 22 Mineral 50 & Limestone+4-20-20 & - & - & - & 0.206 & 0.407 & 0.322 \\
\hline 23 Mixed & Limestone+ $\mathrm{MV}^{1}+\mathrm{MC}^{2}$ & - & - & - & 0.411 & 0.813 & 0.644 \\
\hline 24 Molasses & Limestone + molasses $+\mathrm{MC}^{2}$ & - & - & - & 0.411 & 0.813 & 0.644 \\
\hline 25 Pure & Limestone $+\mathrm{CP}^{3}+\mathrm{MC}^{2}$ & - & - & - & 0.411 & 0.813 & 0.644 \\
\hline
\end{tabular}


BIOFOM pots at dose 100 for the respective sources (mixed, molasses and broth) and concentrations (30\% and 45\% TSS) were, respectively, $19.498 \mathrm{~g}, 20.942 \mathrm{~g}, 15.180 \mathrm{~g}, 19.168 \mathrm{~g}$, 21.040 and $\mathrm{g} 22.561 \mathrm{~g}$ of product per pot. The pots at doses 75 and 50 were given the above mentioned percentage quantities. The pots with mixed vinasse $\left(\mathrm{T}_{23}\right)$, molasses $\left(\mathrm{T}_{24}\right)$ and broth $\left(\mathrm{T}_{25}\right)$ each received a total of $0.644 \mathrm{~g} \mathrm{KCl}$, and for the first two cases, $0.277 \mathrm{~g}$ and for the third case, 0.290 $\mathrm{g}$ of $\mathrm{KCl}$ equivalent as vinasse. As for the triple superphosphate (TSP), these treatments received in total per pot $0.813 \mathrm{~g}$, with $0.019 \mathrm{~g}, 0.024 \mathrm{~g} 0,051 \mathrm{~g}$ the equivalent amounts of vinasse. The same was true for urea, whose total dose per pot, $\mathrm{T}_{23}, \mathrm{~T}_{24}$ and $\mathrm{T}_{25}$, corresponded to $0.411 \mathrm{~g}$, however, from this total, $0.048 \mathrm{~g}, 0.057 \mathrm{~g}$ and $0.087 \mathrm{~g}$ corresponded to the equivalent amounts in vinasse.

Soil used in the experiment was removed from the first $25 \mathrm{~cm}$ surface Red-Yellow Ultisol medium texture (more than $25 \%$ clay in the B horizon), with the chemical characteristics given by soil analysis of the Soil Laboratory from the "Luiz de Queiroz" College of Agriculture, University of São Paulo. These analysis results were used to calculate the amount of dolomite limestone added to the soil to correct it.

Each pot contained 2.5 liter capacity, to which $2 \mathrm{~kg}$ of soil was added (with density of

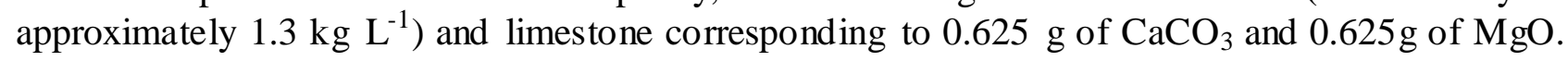
BIOFOM granules and fertilizer for each treatment were homogenized with the soil from the bottom half of the pot and then supplemented with soil in the upper half. After liming and fertilizing, aiming at accelerating the effect of limestone, the pots were kept at water pot capacity (CASAROLI \& VAN LIER, 2008) for seven days. Soil within pots was saturated with water in a recipient until saturation by capillary action was reached, what occurred after two days. Immediately after, they were covered with plastic film to prevent evaporation and placed to drain freely, weighing the mass after a period superior to 24 hours. From the gravimetric method (GARDNER, 1986), the values of water content in the soil were obtained. Then two corn seeds were sown per pot, using the Dow-2B-710 corn variety, whose emergence occurred uniformly in three days. After 8 days from sowing, thinning was performed leaving only one plant per pot.

Pot irrigation after the incubation period was carried out daily and irrigation quantification was performed with the gravimetric method mentioned above.

At 50 days after emergence, samples were taken and results evaluated with respect to the following variables leaf area (LA), by leaf area integrator LI-Cor ${ }^{\circledR}$ model LI 3100; shoot and root dry mass (SDM and RDM), by drying in an oven with air-ventilation at $65{ }^{\circ} \mathrm{C}$ for 48 hours. Macro and micronutrients were measured in plant shoot. Thus, the dry plant material was weighed and ground in Willey type mill and sampled to quantify macro and micronutrients, as described in MALAVOLTA et al., (1997).

Differences among treatments was performed by Tukey test (significance level at 5\% probability). Statistical analysis was performed using SAS 9.2 software (Statistical Analysis System).

\section{RESULTS AND DISCUSSION}

In relation to chemical fertilizer, the BIOFOM formulated presents similar particle size, but its production cost is shared with other processes such as production of sugar, ethanol and electricity. Compared to natural vinasse, the BIOFOM has no odor, has facilitated application because it is solid and grainy, and does not suffer percolation into the ground.

Vinasse can be originated from fermenting of different wort types: from molasses, from broth and mixed (broth + molasses). Vinasse from molasses has higher concentrations than broth and mixed have of the following items: soluble mineral waste, $\mathrm{P}, \mathrm{K}, \mathrm{Ca}, \mathrm{Mg}, \mathrm{Mn}, \mathrm{Zn}$ and $\mathrm{Na}$ (Table $3)$. 
TABLE 3. Physical-chemical analysis of the organomineral fertilizers (BIOFOM) used.

\begin{tabular}{|c|c|c|c|c|c|c|}
\hline \multirow{3}{*}{ Determinations } & \multicolumn{2}{|c|}{ Pure broth } & \multicolumn{2}{|c|}{ Molasses } & \multicolumn{2}{|c|}{ Mixed broth } \\
\hline & $30 \%$ & $45 \%$ & $30 \%$ & $45 \%$ & $30 \%$ & $45 \%$ \\
\hline & TSS1 & TSS & TSS & TSS & TSS & TSS \\
\hline $\mathrm{pH}$ in $\mathrm{CaCl}(0.01 \mathrm{M})$ & 6.2 & 5.8 & 6.5 & 6.5 & 6.7 & 6.5 \\
\hline Density (g.cm-3) & 0.52 & 0.58 & 0.50 & 0.52 & 0.54 & 0.57 \\
\hline Humidity lost at $60-65^{\circ} \mathrm{C}(\%)$ & 4.20 & 3.89 & 3.66 & 3.45 & 3.30 & 3.92 \\
\hline Humidity lost between 65 and $110^{\circ} \mathrm{C}(\%)$ & 4.22 & 3.84 & 4.29 & 4.22 & 5.81 & 4.6 \\
\hline Total humidity $(\%)$ & 8.42 & 7.73 & 7.95 & 7.76 & 9.01 & 8.52 \\
\hline Total organic matter (combustion) $(\%)$ & 46.84 & 43.9 & 46.4 & 43.72 & 44.83 & 39.8 \\
\hline Compost organic matter $(\%)$ & 45.44 & 41.45 & 41.55 & 41.6 & 41.73 & 36.25 \\
\hline Organic matter resistant to composting (\%) & 1.40 & 2.45 & 4.85 & 2.12 & 3.10 & 3.55 \\
\hline Total carbon (organic and mineral) $(\%)$ & 26.02 & 24.39 & 25.78 & 24.29 & 24.91 & 22.11 \\
\hline Organic carbon $(\%)$ & 25.24 & 23.03 & 23.08 & 21.11 & 23.19 & 20.14 \\
\hline Total mineral waste $(\%)$ & 44.73 & 48.37 & 45.65 & 48.52 & 46.16 & 51.68 \\
\hline Insoluble mineral waste $(\%)$ & 28.55 & 33.74 & 23.56 & 29.84 & 28.77 & 35.83 \\
\hline Soluble mineral waste $(\%)$ & 16.18 & 14.63 & 22.09 & 18.68 & 17.39 & 15.85 \\
\hline Total nitrogen $(\%)$ & 2.81 & 3.82 & 2.56 & 3.33 & 4.53 & 3.84 \\
\hline Phosphorous (P2O5) total (\%) & 2.17 & 2.57 & 2.66 & 2.31 & 2.54 & 2.39 \\
\hline Potassium (K2O) total (\%) & 4.30 & 4.01 & 5.96 & 4.72 & 4.64 & 4.32 \\
\hline Calcium $(\mathrm{Ca})$ total $(\%)$ & 2.17 & 2.50 & 2.81 & 2.56 & 2.45 & 2.42 \\
\hline Magnesium $(\mathrm{Mg})$ total $(\%)$ & 0.51 & 0.53 & 0.6 & 0.59 & 0.51 & 0.48 \\
\hline Sulfur (S) total $(\%)$ & 0.28 & 0.28 & 0.40 & 0.58 & 0.31 & 0.27 \\
\hline Ratio C/N (total C and total N) & $9 / 1$ & $16 / 1$ & $10 / 1$ & $7 / 1$ & $5 / 1$ & $6 / 1$ \\
\hline Ratio $\mathrm{C} / \mathrm{N}$ (organic $\mathrm{C}$ and total $\mathrm{N}$ ) & $9 / 1$ & $15 / 1$ & $9 / 1$ & $7 / 1$ & $5 / 1$ & $5 / 1$ \\
\hline Total copper $(\mathrm{Cu})(\mathrm{mg} . \mathrm{kg}-1)$ & 36 & 41 & 38 & 39 & 51 & 36 \\
\hline Total manganese (Mn) (mg.kg-1) & 1013 & 1226 & 1322 & 1122 & 1154 & 1139 \\
\hline Total Zinc (Zn) (mg.kg-1) & 167 & 213 & 224 & 183 & 208 & 197 \\
\hline Total iron (Fe) (mg.kg-1) & 11665 & 13865 & 12022 & 11845 & 11738 & 12898 \\
\hline Total boron (B) (mg.kg-1) & 2 & 2 & 2 & 2 & 2 & 2 \\
\hline Total sodium (Na) (mg.kg-1) & 1769 & 1343 & 2693 & 2408 & 1681 & 1486 \\
\hline Hardness (kgf.cm-2) & 1.28 & 1.19 & 0.96 & 1.43 & 1.54 & 1.44 \\
\hline
\end{tabular}

TSS: total soluble solids.

For the variables in Table 4, the leaf area (LA) values had coefficient of variation of $12.47 \%$ and significant minimum deviation of $879.2 \mathrm{~cm}^{2}$ plant $^{-1}$. In the dry weight of plant shoot (SDM), the results showed coefficient of variation of $7.97 \%$ and significant minimum deviation of $5.81 \mathrm{~g} \mathrm{plant}^{-}$ 1 , and regarding the dry weight of roots (RDM), the coefficient of variation was of $7.87 \%$ and the significant minimum deviation of $1.92 \mathrm{~g} \mathrm{plant}^{-1}$. 
TABLE 4. Leaf area (LA, $\mathrm{cm}^{2}$ plant $^{-1}$ ), dry material mass of the corn plants aerial part (SDM, $\mathrm{g}$ plant $\left.^{-1}\right)$, mass of dry material from the roots of corn plants (RDM, g plant ${ }^{-1}$ ).

\begin{tabular}{|c|c|c|c|c|}
\hline & Treatment & LA & SDM & RDM \\
\hline 1 & Control & $546.1 \mathrm{~F}$ & $3.27 \mathrm{H}$ & $8.25 \mathrm{C}$ \\
\hline 2 & Mixed - 30-50 & $2781.6 \mathrm{CDE}$ & 14.52 BCDEF & $8.72 \mathrm{BC}$ \\
\hline 3 & Mixed - 30-75 & 2498.8 CDE & 9.92 FG & $8.86 \mathrm{ABC}$ \\
\hline 4 & Mixed - 30-100 & 2113.6 DE & $5.76 \mathrm{GH}$ & $8.10 \mathrm{C}$ \\
\hline 5 & Mixed - 45-50 & $2759.0 \mathrm{CDE}$ & $13.31 \mathrm{DEF}$ & $8.98 \mathrm{ABC}$ \\
\hline 6 & Mixed - 45-75 & 2752.5 CDE & $12.12 \mathrm{EF}$ & $8.67 \mathrm{ABC}$ \\
\hline 7 & Mixed - 45-100 & $2361.1 \mathrm{DE}$ & $9.55 \mathrm{FG}$ & $8.50 \mathrm{ABC}$ \\
\hline 8 & Molasses - 30-50 & $1961.9 \mathrm{E}$ & 15.35 ABCDEF & $10.42 \mathrm{~A}$ \\
\hline 9 & Molasses - 30-75 & $2293.0 \mathrm{DE}$ & 15.83 ABCDE & $9.31 \mathrm{ABC}$ \\
\hline 10 & Molasses - 30-100 & 2653.7 CDE & 15.92 ABCDE & $10.22 \mathrm{AB}$ \\
\hline 11 & Molasses - 45-50 & $2767.3 \mathrm{CDE}$ & $13.89 \mathrm{CDEF}$ & $9.14 \mathrm{ABC}$ \\
\hline 12 & Molasses - 45-75 & $2675.2 \mathrm{CDE}$ & 13.77 CDEF & 8.39 BC \\
\hline 13 & Molasses - 45-100 & 2902.5 BCD & $13.26 \mathrm{DEF}$ & $8.33 \mathrm{BC}$ \\
\hline 14 & Pure - 30-50 & $2098.8 \mathrm{DE}$ & 14.36 BCDEF & $8.91 \mathrm{ABC}$ \\
\hline 15 & Pure - 30-75 & $2490.3 \mathrm{CDE}$ & 15.30 ABCDEF & $9.92 \mathrm{ABC}$ \\
\hline 16 & Pure - 30-100 & $2848.8 \mathrm{CD}$ & 15.15 ABCDEF & $9.19 \mathrm{ABC}$ \\
\hline 17 & Pure - 45-50 & $2450.7 \mathrm{DE}$ & 15.32 ABCDEF & $9.79 \mathrm{ABC}$ \\
\hline 18 & Pure - 45-75 & 2701.8 CDE & 16.10 ABCDE & $8.55 \mathrm{ABC}$ \\
\hline 19 & Pure - 45-100 & $2870.1 \mathrm{CD}$ & 14.94 ABCDEF & $9.07 \mathrm{ABC}$ \\
\hline 20 & Mineral - 100 & $3771.0 \mathrm{AB}$ & $20.42 \mathrm{~A}$ & $9.14 \mathrm{ABC}$ \\
\hline 21 & Mineral - 75 & $3891.3 \mathrm{~A}$ & $19.51 \mathrm{ABC}$ & $9.64 \mathrm{ABC}$ \\
\hline 22 & Mineral - 50 & $3361.5 \mathrm{ABC}$ & 17.68 ABCDE & $9.38 \mathrm{ABC}$ \\
\hline 23 & Mixed & 2812.4 CDE & $19.79 \mathrm{AB}$ & $8.66 \mathrm{ABC}$ \\
\hline 24 & Molasses & 2527.8 CDE & $18.72 \mathrm{ABCD}$ & $9.27 \mathrm{ABC}$ \\
\hline 25 & Pure & 2616.3 CDE & 18.36 ABCD & $9.81 \mathrm{ABC}$ \\
\hline
\end{tabular}

* Same letters indicate that the means do not differ significantly to the 5\% level of significance by the Tukey test.

As for the leaf area, the three doses of mineral fertilizer $\left(\mathrm{T}_{20}, \mathrm{~T}_{21}\right.$ and $\left.\mathrm{T}_{22}\right)$ showed no significant differences among them, and treatments 20 and 22 showed no significant differences of molasses vinasse BIOFOM 45 at dose $100\left(\mathrm{~T}_{13}\right)$. Dose 50 of the mineral fertilizer $\left(\mathrm{T}_{22}\right)$ showed no significant differences from doses 50 and 75 of mixed vinasse BIOFOM 30 and $45\left(\mathrm{~T}_{2}, \mathrm{~T}_{3}, \mathrm{~T}_{5}\right.$ and $\mathrm{T}_{6}$ ), from dose 100 of molasses BIOFOM $30\left(\mathrm{~T}_{10}\right)$ and from dose 3 of molasses BIOFOM $45\left(\mathrm{~T}_{11}\right.$, $\mathrm{T}_{12}$ and $\left.\mathrm{T}_{13}\right)$, from doses 75 and 100 of broth vinasse BIOFOM 30 and $45\left(\mathrm{~T}_{15}, \mathrm{~T}_{16}, \mathrm{~T}_{18}\right.$ and $\left.\mathrm{T}_{19}\right)$ and from the three concentrated vinasse at $30 \%$ total solids, with the mineral supplementation corresponding to dose 100 of the mineral fertilizer $\left(T_{23}, T_{24}\right.$ and $\left.T_{25}\right)$. For this parameter, the Control differed significantly from all other treatments.

BIOFOM performance, of molasses vinasse concentrated at $30 \%$ total solids at any dose, can be understood as satisfactory when compared to the treatment of mineral fertilizers 100 (S20). In the same way, it can be noted for BIOFOM from pure broth vinasse concentrated $30 \%$ or $45 \%$ TSS, except for $\mathrm{T}_{14}$, concentrated at $30 \%$ TSS, which has a dose of $50 \%$ of the dose of the mineral fertilizer.

For plant shoot dry material, the three doses of mineral fertilizer $\left(T_{20}, T_{21}\right.$ and $\left.T_{22}\right)$ showed no significant differences among them or from the three doses of broth vinasse BIOFOM 30 and 45 ( $\mathrm{T}_{14}$ to $\left.\mathrm{T}_{19}\right)$, from the three doses of molasses vinasse BIOFOM $30\left(\mathrm{~T}_{8}, \mathrm{~T}_{9}\right.$ and $\left.\mathrm{T}_{10}\right)$ and from the three vinasse concentrated at $30 \%$ total solids, with mineral complementation corresponding to dose 100 of the mineral fertilizer $\left(\mathrm{T}_{23}, \mathrm{~T}_{24}\right.$ and $\left.\mathrm{T}_{25}\right)$.

The fact that the treatments with the application of mineral fertilizer have promoted larger leaf area and dry matter mass of plant shoot shows that part of the nutrients in BIOFOM was not available until 45 days after application. This is an advantage when working in an open system, 
where leaching of mobile nutrients may occur. In this experiment, once it is a closed system (vessels), this loss did not occur; leading treatments in which fertilization with mineral fertilizers was made to have higher efficiency, which will certainly not occur in the field.

For root dry mass, dose 50 of molasses vinasse BIOFOM $30\left(\mathrm{~T}_{8}\right)$ only showed significant difference from molasses vinasse BIOFOM 45 at doses 75 and 100 ( $\mathrm{T}_{12}$ and $\mathrm{T}_{13}$ ), from the mixed vinasse BIOFOM 30 at doses 50 and $100\left(\mathrm{~T}_{2}\right.$ and $\left.\mathrm{T}_{4}\right)$ and from the control. For this parameter, the witness only differed from treatments of mixed vinasse BIOFOM 30, at doses 100 and 50 ( $\mathrm{T}_{8}$ and $\left.\mathrm{T}_{10}\right)$.

Table 5 presents the average values of four replicates of the main macronutrients accumulation in the shoots of maize plants.

TABLE 5 - Accumulation of macronutrients (mg plant-1) in aerial part of corn plants.

\begin{tabular}{|c|c|c|c|c|c|c|}
\hline Treatments & $\mathrm{N}$ & $\mathrm{P}$ & $\mathrm{K}$ & $\mathrm{Ca}$ & $\mathrm{Mg}$ & $\mathrm{S}$ \\
\hline 1 Control & $35.44 \mathrm{D}$ & $2.82 \mathrm{I}$ & $33.56 \mathrm{D}$ & $12.61 \mathrm{E}$ & $25.57 \mathrm{E}$ & $2.96 \mathrm{D}$ \\
\hline 2 Mixed $30-50$ & $195.68 \mathrm{C}$ & 20.54DEFGH & $357.83 \mathrm{BC}$ & $44.55 \mathrm{BCD}$ & $65.15 \mathrm{AB}$ & $15.71 \mathrm{BC}$ \\
\hline 3 Mixed 30-75 & $226.12 \mathrm{C}$ & 24.79 CDEFGH & $369.62 \mathrm{BC}$ & $35.98 \mathrm{CDE}$ & $38.18 \mathrm{BCDE}$ & $14.30 \mathrm{BC}$ \\
\hline 4 Mixed 30-100 & 161.47 CD & $11.91 \mathrm{HI}$ & $236.12 \mathrm{CD}$ & $22.19 \mathrm{DE}$ & $28.34 \mathrm{DE}$ & 11.17 CD \\
\hline 5 Mixed 45-50 & $214.73 \mathrm{C}$ & 18.63 EFGHI & $365.16 \mathrm{BC}$ & $45.00 \mathrm{BCD}$ & $57.03 \mathrm{ABC}$ & $14.94 \mathrm{BC}$ \\
\hline 6 Mixed 45-75 & $236.80 \mathrm{C}$ & $23.98 \mathrm{CDEFGH}$ & 424.17 A BC & $36.25 \mathrm{CDE}$ & 46.58 A BCDE & $15.75 \mathrm{BC}$ \\
\hline 7 Mixed 45-100 & $222.01 \mathrm{C}$ & 23.37 CDEFGH & $362.87 \mathrm{BC}$ & $31.22 \mathrm{CDE}$ & $31.87 \mathrm{CDE}$ & $14.84 \mathrm{BC}$ \\
\hline 8 Molasses 30-50 & $158.96 \mathrm{CD}$ & 18.00 EFGHI & $348.11 \mathrm{BC}$ & $42.15 \mathrm{BCD}$ & 45.28 A BCDE & $10.30 \mathrm{CD}$ \\
\hline 9 Molasses 30-75 & $190.44 \mathrm{C}$ & $24.82 \mathrm{CDEFGH}$ & $540.78 \mathrm{AB}$ & $55.06 \mathrm{ABC}$ & $51.17 \mathrm{ABCDE}$ & $12.52 \mathrm{BCD}$ \\
\hline 10 Molasses $30-100$ & $213.21 \mathrm{C}$ & $25.98 \mathrm{CDEFGH}$ & $608.35 \mathrm{AB}$ & $55.03 \mathrm{~A} \mathrm{BC}$ & $51.27 \mathrm{ABCDE}$ & $16.95 \mathrm{ABC}$ \\
\hline 11 Molasses 45-50 & $190.52 \mathrm{C}$ & 18.21 EFGHI & $366.50 \mathrm{BC}$ & $47.34 \mathrm{BC}$ & $46.50 \mathrm{ABCDE}$ & $12.13 \mathrm{CD}$ \\
\hline 12Molasses 45-75 & $197.61 \mathrm{C}$ & $23.02 \mathrm{CDEFGH}$ & $531.62 \mathrm{ABC}$ & $49.72 \mathrm{ABC}$ & 49.77 A BCDE & $15.14 \mathrm{BC}$ \\
\hline 13 Molasses 45-100 & $231.01 \mathrm{C}$ & 27.18 CDEFGH & $418.67 \mathrm{ABC}$ & $51.42 \mathrm{ABC}$ & 42.74 A BCDE & 16.91 A BC \\
\hline 14 Pure 30-50 & $131.86 \mathrm{CD}$ & $15.02 \mathrm{GHI}$ & 314.73 BCD & $38.61 \mathrm{BCD}$ & 49.04 A BCDE & $9.23 \mathrm{CD}$ \\
\hline 15 Pure $30-75$ & $167.44 \mathrm{CD}$ & 19.69 DEFGH & $432.04 \mathrm{ABC}$ & $39.68 \mathrm{BCD}$ & $51.90 \mathrm{ABCDE}$ & $12.39 \mathrm{BCD}$ \\
\hline 16Pure $30-100$ & $223.77 \mathrm{C}$ & 24.12 CDEFGH & $378.33 \mathrm{BC}$ & $43.18 \mathrm{BCD}$ & $43.58 \mathrm{ABCDE}$ & $15.49 \mathrm{BC}$ \\
\hline 17 Pure 45-50 & $193.29 \mathrm{C}$ & 17.01 FGHI & $350.47 \mathrm{BC}$ & $36.09 \mathrm{CDE}$ & 55.28 A BCD & $12.62 \mathrm{BCD}$ \\
\hline 18 Pure $45-75$ & $231.84 \mathrm{C}$ & $23.67 \mathrm{CDEFGH}$ & $448.34 \mathrm{~A} \mathrm{BC}$ & $38.10 \mathrm{BCD}$ & $58.36 \mathrm{ABC}$ & $13.80 \mathrm{BC}$ \\
\hline 19Pure 45-100 & $255.18 \mathrm{BC}$ & 29.24 CDEFG & 468.91 A BC & $41.07 \mathrm{BCD}$ & $51.69 \mathrm{ABCDE}$ & 17.24 A BC \\
\hline 20 Mineral 100 & $490.73 \mathrm{~A}$ & $71.43 \mathrm{~A}$ & $702.79 \mathrm{~A}$ & $73.20 \mathrm{~A}$ & $60.66 \mathrm{AB}$ & $26.06 \mathrm{~A}$ \\
\hline 21 Mineral 75 & 369.68 A B & $51.91 \mathrm{~B}$ & $613.54 \mathrm{AB}$ & $60.44 \mathrm{AB}$ & $61.77 \mathrm{AB}$ & $22.38 \mathrm{AB}$ \\
\hline 22 Mineral 50 & $245.05 \mathrm{BC}$ & $35.17 \mathrm{CD}$ & $396.95 \mathrm{BC}$ & $47.13 \mathrm{BC}$ & $70.22 \mathrm{~A}$ & $14.38 \mathrm{BC}$ \\
\hline 23 Mixed & $226.06 \mathrm{C}$ & $38.20 \mathrm{BC}$ & 503.61 A BC & $46.50 \mathrm{BC}$ & $55.54 \mathrm{ABCD}$ & $17.69 \mathrm{ABC}$ \\
\hline 24Molasses & $184.84 \mathrm{C}$ & $33.23 \mathrm{CDE}$ & $457.79 \mathrm{ABC}$ & $38.91 \mathrm{BCD}$ & $55.12 \mathrm{ABCD}$ & $13.87 \mathrm{BC}$ \\
\hline 25Pure & $185.88 \mathrm{C}$ & $31.33 \mathrm{CDEF}$ & $442.25 \mathrm{ABC}$ & $48.73 \mathrm{BC}$ & $59.94 \mathrm{ABC}$ & $14.26 \mathrm{BC}$ \\
\hline
\end{tabular}

* Same letters indicate that the means do not differ significantly at the 5\% level of significance by the Tukey test.

Nitrogen $(\mathbf{N})$ : The results showed a coefficient of variation of $22.82 \%$ and significant minimum deviation of $132.08 \mathrm{mg} \mathrm{plant}^{-1}$. Dose of 100 of the mineral fertilizer $\left(\mathrm{T}_{20}\right)$ was not significantly different from dose $75\left(\mathrm{~T}_{21}\right)$, nor the latter from dose $50\left(\mathrm{~T}_{22}\right)$ and from dose 100 of the broth vinasse BIOFOM $45\left(\mathrm{~T}_{19}\right)$. All other treatments of BIOFOM and concentrated and complemented vinasse did not differ significantly from $T_{22}$. Mass productivity of the aerial part of the Control treatment was significantly lower than all other treatments due to the low supply of nutrients.

Phosphorus (P): The results for this nutrient showed a coefficient of variation of $22.58 \%$, and a significant minimum deviation of $15.87 \mathrm{mg} \mathrm{plant}^{-1}$. Dose 100 of the mineral fertilizer $\left(\mathrm{T}_{20}\right)$ showed significant difference from dose $75\left(\mathrm{~T}_{21}\right)$ and this, in turn, did not differ significantly from vinasse molasses + broth, supplemented with mineral fertilizer $\left(\mathrm{T}_{23}\right)$. All BIOFOM treatments and other complemented vinasse did not differ significantly from dose 50 of the mineral fertilizer $\left(\mathrm{T}_{22}\right)$, except for the treatments of broth vinasse and molasses vinasse BIOFOM 30 and 45 at dose $50\left(\mathrm{~T}_{8}\right.$, $\mathrm{T}_{11}, \mathrm{~T}_{14}$ and $\left.\mathrm{T}_{17}\right)$, the molasses vinas se + broth 30 at dose $100\left(\mathrm{~T}_{4}\right)$ and the molasses vinasse + broth 45 at dose $50\left(\mathrm{~T}_{5}\right)$ which did not differ significantly from the Control. The fact that the treatments with doses 100 and 75 of the mineral fertilizer $\left(T_{20}\right.$ and $\left.T_{21}\right)$ promoted greater phosphorus 
accumulation in plant shoot shows that part of the phosphorus present in the BIOFOM was not available until 45 days after application.

Potassium (K): The results showed a coefficient of variation of $26.82 \%$, and a minimum significant deviation of $302.22 \mathrm{mg} \mathrm{plant}^{-1}$. Dose 100 of the mineral fertilizer $\left(\mathrm{T}_{20}\right)$ was not significantly different from dose $75\left(\mathrm{~T}_{21}\right)$, from the three concentrated and supplemented vinasse $\left(\mathrm{T}_{23}, \mathrm{~T}_{24}\right.$ and $\left.\mathrm{T}_{25}\right)$ and from broth vinasse BIOFOM 45, at doses 75 and $100\left(\mathrm{~T}_{18}\right.$ and $\left.\mathrm{T}_{19}\right)$, from broth vinasse BIOFOM 30 at dose 75 ( $\left.\mathrm{T}_{15}\right)$, from molasses vinasse BIOFOM 30 and 45, at doses 75 and $100\left(\mathrm{~T}_{9}, \mathrm{~T}_{10}, \mathrm{~T}_{12}\right.$ and $\left.\mathrm{T}_{13}\right)$, and from mixed vinasse BIOFOM 45, at dose $75\left(\mathrm{~T}_{6}\right)$. The control, without fertilizer application, resulted in the lowest values of $\mathrm{K}$ accumulation in the aerial part, not differing only from treatments Mixed 30-100 ( $\left.\mathrm{T}_{4}\right)$ and Pure 30-50 $\left(\mathrm{T}_{14}\right)$, but differing from the others.

Calcium (Ca): The results showed coefficient of variation of $22.75 \%$, and a minimum significant deviation of $24.12 \mathrm{mg} \mathrm{plant}^{-1}$. Dose 100 of the mineral fertilizer $\left(\mathrm{T}_{20}\right)$ was not significantly different from dose $75\left(\mathrm{~T}_{21}\right)$ and from molasses vinasse BIOFOM 30 and 45 at doses 75 and $100\left(\mathrm{~T}_{9}, \mathrm{~T}_{10}, \mathrm{~T}_{12}\right.$ and $\left.\mathrm{T}_{13}\right)$. Dose 75 of the mineral fertilizer $\left(\mathrm{T}_{21}\right)$ showed a significant difference from broth vinasse BIOFOM 30 at dose $50\left(\mathrm{~T}_{14}\right)$, from mixed vinasse BIOFOM 30 and 45 at doses 75 and $100\left(\mathrm{~T}_{3}, \mathrm{~T}_{4}, \mathrm{~T}_{6}\right.$ and $\left.\mathrm{T}_{7}\right)$ and broth vinasse BIOFOM 45 at dose $50\left(\mathrm{~T}_{17}\right)$. Control did not differ only from treatments $\mathrm{T}_{3}, \mathrm{~T}_{4}, \mathrm{~T}_{6}, \mathrm{~T}_{7}$ and $\mathrm{T}_{17}$. The fact that the treatments with the application of mineral fertilizer at doses 100 and 75 promoted higher calcium accumulation in plant shoot is due to the greater availability of $\mathrm{N}, \mathrm{P}$ and $\mathrm{K}$ to the plant in the first 45 days, which did not occur in the same magnitude with plants receiving complemented vinasse and BIOFOM.

Magnesium (Mg): For Mg, the results showed a coefficient of variation of $20.86 \%$, and a minimum significant deviation of $28.12 \mathrm{mg} \mathrm{plant}^{-1}$. All three doses of mineral fertilizer $\left(\mathrm{T}_{20}, \mathrm{~T}_{21}\right.$ and $\mathrm{T}_{22}$ ) showed no significant difference among them and against BIOFOM treatments, except the mixed vinasse 30 at dose $100\left(\mathrm{~T}_{4}\right)$, and the mixed vinasse 45 at dose $100\left(\mathrm{~T}_{7}\right)$. The control differed significantly from the three complemented vinasse $\left(T_{23}\right.$ to $\left.T_{25}\right)$, from the three doses of mineral fertilizer, from broth vinasse BIOFOM 45 at doses 50 and $75\left(\mathrm{~T}_{17}\right.$ and $\left.\mathrm{T}_{18}\right)$ and from mixed vinasse BIOFOM 30 and 45 at dose $50\left(\mathrm{~T}_{2}\right.$ and $\left.\mathrm{T}_{5}\right)$.

Sulfur (S): For this parameter, the results showed a coefficient of variation of $25.64 \%$, and a minimum significant deviation of $10.02 \mathrm{mg} \mathrm{plant}^{-1}$. Doses 100 and 75 of the mineral fertilizer $\left(\mathrm{T}_{20}\right.$ and $\left.\mathrm{T}_{21}\right)$ showed no significant difference between them and the complemented mixed vinasse $\left(\mathrm{T}_{23}\right)$, the broth vinasse BIOFOM 45 at dose $100\left(\mathrm{~T}_{19}\right)$ and the molasses vinasse BIOFOM 45 and 30 at dose $100\left(T_{10}\right.$ and $\left.T_{13}\right)$. Dose 75 of the mineral fertilizer $\left(T_{21}\right)$ showed a significant difference from the Control and from broth vinasse BIOFOM 30 at dose $50\left(\mathrm{~T}_{14}\right)$, from molasses vinasse 45 and 30 at dose $50\left(\mathrm{~T}_{8}\right.$ and $\left.\mathrm{T}_{11}\right)$ and from mixed vinasse 30 at dose $100\left(\mathrm{~T}_{4}\right)$. The Control differed significantly from the three complemented vinasse $\left(T_{23}\right.$ to $\left.T_{25}\right)$, from the three doses of mineral fertilizer $\left(\mathrm{T}_{20}\right.$ to $\left.\mathrm{T}_{22}\right)$, from the broth vinasse and molasses vinasse BIOFOM 45 at doses 100 and 75 $\left(\mathrm{T}_{12}, \mathrm{~T}_{13}, \mathrm{~T}_{18}\right.$ and $\left.\mathrm{T}_{19}\right)$, from the molasses and broth vinasse BIOFOM 30 at dose $100\left(\mathrm{~T}_{10}\right.$ and $\left.\mathrm{T}_{16}\right)$, from the mixed vinasse BIOFOM 45 at the three doses $\left(\mathrm{T}_{5}\right.$ to $\left.\mathrm{T}_{7}\right)$ and from molasses vinasse BIOFOM + broth 30 at doses 75 and $50\left(\mathrm{~T}_{2}\right.$ and $\left.\mathrm{T}_{3}\right)$.

In general, it was noted that treatments $T_{20}$ and $T_{21}$, with the application of doses 100 and 75 of the mineral fertilizer, promoted greater accumulation of $\mathrm{N}, \mathrm{P}$ and $\mathrm{K}$ in plant shoot, showing that part of these nutrients in the BIOFOM was not available within 45 days after application - which is an advantage when working in an open system where there is leaching of mobile nutrients in the soil. In the experiment, because it is a closed system (pots), this loss did not occur, leading treatments where the fertilization with mineral fertilizers was performed to present a slightly higher efficiency, which should not occur in the field.

For sugar cane, whose cycle is from 12 to 18 months, long enough for the rest of the N, P, K of the BIOFOM to be made available in an open system, BIOFOM behavior can be expected to be similar, or even better than those with mineral fertilizer. 
Table 6 shows the experimental results regarding the accumulation of the main micronutrients within corn plant shoot.

TABLE 6 - Accumulation of micronutrients ( $\mu \mathrm{g}$ plant-1) in aerial part of corn plants.

\begin{tabular}{|c|c|c|c|c|c|}
\hline Treatment & B & $\mathrm{Cu}$ & $\mathrm{Fe}$ & $\mathrm{Mn}$ & $\mathrm{Zn}$ \\
\hline 1 Control & $77.15 \mathrm{~B}$ & $18.87 \mathrm{D}$ & $402.14 \mathrm{E}$ & $937.57 \mathrm{~F}$ & $18.48 \mathrm{E}$ \\
\hline 2 Mixed 30-50 & $306.94 \mathrm{AB}$ & $100.14 \mathrm{ABC}$ & 1373.92 ABCDE & 9824.32 CDE & 539.36 A BCD \\
\hline 3 Mixed 30-75 & $275.90 \mathrm{AB}$ & $87.51 \mathrm{BCD}$ & 1151.89 BCDE & 8199.16 CDEF & $408.88 \mathrm{CD}$ \\
\hline 4 Mixed 30-100 & $166.46 \mathrm{AB}$ & $47.25 \mathrm{CD}$ & $787.82 \mathrm{DE}$ & $5455.51 \mathrm{EF}$ & 247.99 DE \\
\hline 5 Mixed 45-50 & $350.54 \mathrm{AB}$ & $83.22 \mathrm{BCD}$ & 1408.22 ABCD & 9135.06 CDE & 524.21 A BCD \\
\hline 6 Mixed 45-75 & $377.47 \mathrm{AB}$ & $94.32 \mathrm{ABC}$ & 1353.43 ABCDE & 8104.59 CDEF & 447.78 BCD \\
\hline 7 Mixed 45-100 & $332.81 \mathrm{AB}$ & $78.21 \mathrm{CD}$ & $940.30 \mathrm{CDE}$ & $6879.79 \mathrm{EF}$ & $349.25 \mathrm{CDE}$ \\
\hline 8 Molasses $30-50$ & $156.84 \mathrm{AB}$ & $75.81 \mathrm{CD}$ & $1670.96 \mathrm{ABCD}$ & 9345.58 CDE & $480.45 \mathrm{ABCD}$ \\
\hline 9 Molasses 30-75 & $353.74 \mathrm{AB}$ & 87.22 BCD & 1645.13 ABCD & $6532.62 \mathrm{EF}$ & 447.14 BCD \\
\hline 10 Molasses $30-100$ & $404.43 \mathrm{AB}$ & $112.30 \mathrm{ABC}$ & 1719.73 ABCD & $7410.00 \mathrm{DEF}$ & 453.77 BCD \\
\hline 11 Molasses 45-50 & $266.01 \mathrm{AB}$ & 73.95 CD & 1419.51 ABCD & $5427.56 \mathrm{EF}$ & 525.57 A BCD \\
\hline 12 Molas ses $45-75$ & $375.91 \mathrm{AB}$ & 89.78 A BCD & 1705.98 ABCD & $7681.92 \mathrm{DEF}$ & 520.17 A BCD \\
\hline 13 Molasses 45-100 & $222.42 \mathrm{AB}$ & $95.02 \mathrm{ABC}$ & 1463.14 ABCD & $9070.85 \mathrm{CDE}$ & $542.96 \mathrm{ABCD}$ \\
\hline 14 Pure $30-50$ & $481.48 \mathrm{AB}$ & $71.66 \mathrm{CD}$ & 1567.92 ABCD & $6635.32 \mathrm{EF}$ & $381.28 \mathrm{CDE}$ \\
\hline 15 Pure $30-75$ & $305.24 \mathrm{AB}$ & $77.13 \mathrm{CD}$ & 1427.05 ABCD & 7774.58 DEF & $450.96 \mathrm{BCD}$ \\
\hline 16 Pure $30-100$ & $383.57 \mathrm{AB}$ & $110.75 \mathrm{ABC}$ & 1579.58 ABCD & 9525.57 CDE & $455.36 \mathrm{BCD}$ \\
\hline 17 Pure $45-50$ & $214.13 \mathrm{AB}$ & $80.89 \mathrm{BCD}$ & $1459.13 \mathrm{ABCD}$ & 8904.68 CDE & 422.29 BCD \\
\hline 18 Pure $45-75$ & $467.17 \mathrm{AB}$ & $82.80 \mathrm{BCD}$ & 1383.64 ABCDE & 10259.91 CDE & $453.20 \mathrm{BCD}$ \\
\hline 19 Pure $45-100$ & $223.48 \mathrm{AB}$ & $109.58 \mathrm{ABC}$ & 1240.20 ABCDE & $9442.37 \mathrm{CDE}$ & 498.91 A BCD \\
\hline 20 Mineral 100 & $511.12 \mathrm{AB}$ & $159.47 \mathrm{~A}$ & $2230.22 \mathrm{~A}$ & $17813.58 \mathrm{AB}$ & $775.77 \mathrm{~A}$ \\
\hline 21 Mineral 75 & $379.33 \mathrm{AB}$ & $151.14 \mathrm{AB}$ & $2104.15 \mathrm{AB}$ & 20910.64 A & $710.36 \mathrm{AB}$ \\
\hline 22 Mineral 50 & $473.87 \mathrm{AB}$ & 106.31 A BC & 1846.04 ABC & $15425.94 \mathrm{ABC}$ & $579.78 \mathrm{ABC}$ \\
\hline 23 Co mpl. Mixed & $447.70 \mathrm{AB}$ & $112.22 \mathrm{ABC}$ & 1905.89 АВC & 14689.61 ABCD & $558.89 \mathrm{ABC}$ \\
\hline 24 Co mpl. Molas ses & $456.87 \mathrm{AB}$ & $91.57 \mathrm{ABC}$ & 1615.97 ABCD & 12105.27 CDE & 505.65 A BCD \\
\hline 25 Co mpl. Pure & $539.51 \mathrm{~A}$ & $112.23 \mathrm{ABC}$ & 1509.33 ABCD & 9363.25 CDE & 506.33 A BCD \\
\hline
\end{tabular}

* Averages in each row, followed by the same letters, do not differ significantly at the $5 \%$ level of significance by the Tukey test.

* Médias, em cada coluna, seguidas de letras iguais não diferem significativamente a 5\% de probabilidade pelo teste de Tukey.

Boron (B): For this micronutrient, the results showed a coefficient of variation of $48.10 \%$, accumulating variations of concentrations of $\mathrm{B}$ and dry material, and a minimum significant deviation of $442.54 \mu \mathrm{g}$ plant $^{-1}$. Control significantly differed only from the complemented broth vinasse $\left(\mathrm{T}_{25}\right)$, and no other treatments differed from each other due to the high coefficient of variation of $\mathrm{B}$ concentrations within corn plant shoot and to the high value of the minimum significant deviation.

Copper $(\mathbf{C u})$ : The results showed a coefficient of variation of $28.82 \%$, and a minimum significant deviation of $71.61 \mu \mathrm{g}$ plant $^{-1}$. All three doses of mineral fertilizer $\left(\mathrm{T}_{20}\right.$ to $\left.\mathrm{T}_{22}\right)$ showed no significant difference among them or against the three supplemented vinasse $\left(T_{23}\right.$ to $\left.T_{25}\right)$, broth vinasse BIOFOM 30 and 45 at dose 100 ( $\mathrm{T}_{16}$ and $\mathrm{T}_{19}$ ), of molasses vinasse 45 at doses 75 and 100 $\left(\mathrm{T}_{12}\right.$ and $\left.\mathrm{T}_{13}\right)$, of molasses vinasse 30 at dose $100\left(\mathrm{~T}_{10}\right)$, of mixed vinasse 45 at dose $75\left(\mathrm{~T}_{6}\right)$ and of mixed vinasse 30 at dose $50\left(\mathrm{~T}_{2}\right)$. Control differed significantly from the three complemented vinasse $\left(T_{23}\right.$ to $\left.T_{25}\right)$, from the three doses of mineral fertilizer, from the broth vinasse BIOFOM 30 and 45 at dose $100\left(\mathrm{~T}_{16}\right.$ and $\left.\mathrm{T}_{19}\right)$, from the molasses vinasse BIOFOM 30 and 45 at dose $100\left(\mathrm{~T}_{10}\right.$ and $\left.\mathrm{T}_{13}\right)$, from the mixed vinasse BIOFOM 45 at dose $75\left(\mathrm{~T}_{6}\right)$ and from mixed vinasse 30 at a dose $50\left(\mathrm{~T}_{2}\right)$.

Iron (Fe): For this nutrient, the results showed coefficient of variation of $25.04 \%$, and a minimum significant deviation of $994.44 \mu \mathrm{g}_{\text {plant }}{ }^{-1}$. All three doses of mineral fertilizer showed no significant differences among them $\left(\mathrm{T}_{20}\right.$ to $\left.\mathrm{T}_{22}\right)$. Treatment $\mathrm{T}_{21}$ differed only from the treatment of molasses vinasse BIOFOM + broth 30 at dose $100\left(\mathrm{~T}_{4}\right)$, from the molasses vinasse BIOFOM treatment + broth 45 at dose $100\left(\mathrm{~T}_{7}\right)$ and Control. Control did not differ from treatments 2, 3, 4, 6, 7, 18 and 19. 
Manganese (Mn): In the case of Mn, the results showed coefficient of variation of $29.31 \%$, and a minimum significant deviation of $7470 \mu \mathrm{g} \mathrm{plant}^{-1}$. All three doses of mineral fertilizer showed no significant difference among them and the complemented mixed vinasse $\left(\mathrm{T}_{23}\right)$. Dose 50 of the mineral fertilizer $\left(\mathrm{T}_{22}\right)$ showed a significant difference from the broth vinasse BIOFOM 30 at doses 50 and $75\left(\mathrm{~T}_{14}\right.$ and $\left.\mathrm{T}_{15}\right)$, from molasses vinasse BIOFOM 45 at doses 50 e $75\left(\mathrm{~T}_{11}\right.$ and $\left.\mathrm{T}_{12}\right)$ and from molasses 30 at doses 75 and $100\left(\mathrm{~T}_{9}\right.$ and $\left.\mathrm{T}_{10}\right)$, from mixed vinasse 30 and 45 at dose $100\left(\mathrm{~T}_{4}\right.$ and $\mathrm{T}_{7}$ ) and from the Control. This, in turn, did not differ significantly, in addition to those which differed from dose 50 of mineral fertilizer, from the mixed vinasse BIOFOM 30 and 45 at dose 75 $\left(\mathrm{T}_{3}\right.$ and $\left.\mathrm{T}_{6}\right)$.

Zinc (Zn): For this parameter, the results showed coefficient of variation of $23.07 \%$, and a minimum significant de viation of $295.34 \mu \mathrm{g}$ plant ${ }^{-1}$. All three doses of mineral fertilizer $\left(\mathrm{T}_{20}\right.$ to $\left.\mathrm{T}_{22}\right)$ showed no significant difference among them or from the three supplemented vinasse $\left(\mathrm{T}_{23}\right.$ to $\left.\mathrm{T}_{25}\right)$, from broth vinasse BIOFOM 45 at dose $100\left(\mathrm{~T}_{19}\right)$, from molasses vinasse BIOFOM 45 in three doses ( $\mathrm{T}_{11}$ to $\left.\mathrm{T} 13\right)$, from molasses vinasse BIOFOM 30 at dose $50\left(\mathrm{~T}_{8}\right)$, from mixed vinasse 30 and 45 at dose $50\left(\mathrm{~T}_{2}\right.$ and $\left.\mathrm{T}_{5}\right)$. Control did not differ significantly from the broth vinasse BIOFOM 30 at dose $50\left(\mathrm{~T}_{14}\right)$, from mixed vinasse 30 and 45 at dose $100\left(\mathrm{~T}_{4}\right.$ and $\left.\mathrm{T}_{7}\right)$.

Organic matter applied via BIOFOM promotes the improvement of soil physicochemical properties, cation exchange capacity and porosity, which favors the nutrient absorption and reduce losses caused by leaching (GURGEL, 2012).

After 60 days from corn planting, it was observed that the BIOFOM was attached to the roots due to its fertilizer condition, wherein the organic matter provides the gradual release of nutrients.

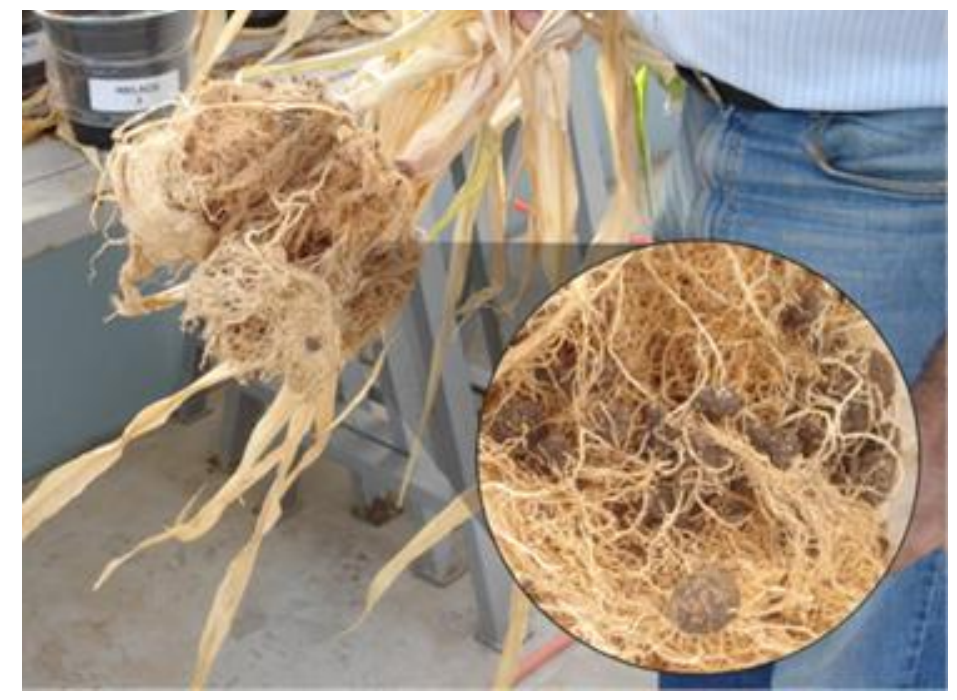

FIGURE 1. BIOFOM granules adhered to roots of corn plant.

The BIOFOM reduces the generation of waste from the sugar and ethanol industry, using the residues rationally to produce organomineral fertilizers.

Thus, BIOFOM is a sustainable solution, and complies with applicable environmental laws. Ordinances, MINTER n 323 of 1978, prohibit the release of vinasse in surface watercourses. Resolutions from CONAMA (National Environment Council), 0002 of 1984 and 0001 of 1986, determine, respectively, the study and development of standards to control effluent from ethanol distilleries and the obligation of performing EIA (Environmental Impact Studies) and RIMA (Report on Environmental Impact) for new plants or expansions of existing ones. Law $n^{\circ}$ 6134/ 1988 (art. 5) of the State of São Paulo determines that waste from activities (industrial and others) must not pollute groundwater. In this sense, waste use benefits the environment because all residue produced within sugarcane processing can be transformed into BIOFOM, minimizing the risk of ground water and soil contamination by washing wastes. 


\section{CONCLUSIONS}

Considering soil type and crop to be grown, we can conclude that BIOFOM can replace the use of mineral fertilizers, and the pure broth vinasse BIOFOM with $30 \%$ and $45 \%$ of total solids and the ones from molasses vinasse with $30 \%$ total solids achieved the same performance of the mineral fertilizers and of the three supplemented vinasse (mineral supplementation corresponding to dose 100 of the mineral fertilizer). Organomineral fertilizers (BIOFOM) from mixed vinasse with $30 \%$ and $45 \%$ total solids and the ones from molasses vinasse with $45 \%$ total solids, with adjustments in the amounts of the mineral fertilizer added, depending on the cropped plant, may have same performance as the mineral fertilizer and the three supplemented vinasse.

The use of BIOFOM, in the context of sugarcane industry, can reduce production costs, especially for the lower cost of mineral fertilizer, transportation, operations and infrastructure, given the elimination of individual application of vinasse, filter cake and ash.

The addition of mineral fertilizer enables the use of wastes from sugar and alcohol industry as a granulate organomineral fertilizer involving the concentration of vinasse, in addition to the aforementioned benefits, also provides the opportunity for reuse of evaporated water in the processes of recirculation and closing of circuits, allowing the minimization of water uptake by sugarcane agribusiness.

\section{REFERENCES}

BRASIL. Ministério do Interior (MINTER). Portaria Minter $n^{\circ} 323$, de 29 de novembro de 1978. Resíduos, Tratamento de Resíduo, água e álcool, energia combustível. Disponível em: http://faolex.fao.org/docs/pdf/bra14330.pdf. Acesso em: 22 jun. 2011.

BRASIL. Ministério do Meio Ambiente. Conselho Nacional do Meio Ambiente. Resolução $n^{\circ}$ 001, de 23 de janeiro de 1986. Dispõe sobre critérios básicos e diretrizes gerais para a avaliação de impacto ambiental. Disponível em: http://www.mma.gov.br/port/conama/legiabre.cfm?codlegi=23. Acesso em: 13 maio. 2011.

BRASIL. Ministério do Meio Ambiente. Conselho Nacional do Meio Ambiente. Resolução $n^{\circ}$ 002, de 5 de junho de 1984. Dispõe sobre a poluição causada pelos efluentes das destilarias de álcool. Disponível em: www.mma.gov.br/port/conama/legiabre.cfm?codlegi=2. Acesso em: 13 maio 2011.

CASAROLI, D.;VAN LIER, Q. J. de. Critérios para determinação da capacidade de vaso. Revista Brasileira de Ciência do Solo, Viçosa, MG, v.32, n.1, p.59-66, 2008.

CÓ JUNIOR, C.; MARQUES, M.C.; TASSO JÚNIOR, L.C. Efeito residual de quatro aplicações anuais de lodo de esgoto e vinhaça na qualidade tecnoló gica da cana-de-açúcar. Engenharia Agrícola, Jaboticabal, v.28, n.1, p.196-203, 2008.

GARDNER, W.H. Water contente: In: LUTE, A. (Ed.) Methods of soil analysis. Madison: American Society of Agronomy, 1986. p.493-544.

GURGEL, M.N.A. A Usina Dedini para prod ução de BIOFOM - Biofertilizante Organomineral. Piracicaba: SIMTEC, 2009a. Disponível em: <www.dedini.com.br>. Acesso em: 10 maio 2011.

GURGEL, M.N.A. Relatório interno da Divisão de Engenharia de Tecnologias. Piracicaba: Dedini, 2009b.

GURGEL, M.N.A. Tecnologia pa ra aproveitamento de resíduos da agroindústria sucroalcooleira como biofertilizante organomineral granulado. 2012. 125 f. Tese (Doutorado em Engenharia Agrícola) - Faculdade de Engenharia Agrícola, Universidade Estadual de Campinas, Campinas, 2012.

MALAVOLTA, E. et al. Avaliação do estado nutricional das plantas: princípios e aplicações. 2.ed. Piracicaba: Potafos, 1997. 319 p. 
RAMOS, H.R.; SOARES, M.C.; ALMEIDA, M.I.R. A Internacionalização do álcool carburante: um estudo do setor sulcroalcooleiro do Brasil. In: CONGRESSO INTERNACIONAL DE LA SOCIEDAD LATINOAMERICANA DE ESTRATEGIA, 21., 2008, Santiago. Anais...Santiago: SLADE, 2008.

SILVA, O.; FISCHETTI, D. Etanol: a revolução verde. São Paulo: Bizz Comunicação e Produções, 2008. 264p.

SPADOTTO, C.A. Gestão de Resíduos: realizações e desafios no setor sucroalcooleiro. Disponível em: <http://www.embrapa.gov.br/imprensa/artigo s/2008/gestao-de-residuos-realizacoes-edesafiosno-setor-sucroalcooleiro>. Acesso em: 1 de out.2008.

SZMRECS ÁNYI, T. Tecnologia e degradação ambiental: o caso da agroindústria canavieira no Estado de São Paulo. Revista Informações Econômicas, São Paulo, v.24, n.10, p.73-81, 1994.

TASSO JUNIOR, L.C.; MARQUES, M.O.; FRANCO, A.; NOGUEIRA, G. A.; NOBILE, F.O.; CAMILOTTI, F.; SILVA, A.R. Produtividade e qualidade de cana-de-açúcar cultivada em solo tratado com lodo de esgoto, vinhaça e adubos minerais. Engenharia Agrícola, Jaboticabal, v.27, n.1, p.276-283, 2007. 